\title{
KEPEMIMPINAN KEPALA SEKOLAH SEBAGAI SEORANG SUPERVISOR DALAM PENGAWASAN KINERJA GURU DI SEKOLAH DASAR
}

\author{
Muhammad Isnaini \\ SDN 7 Terara, Lombok Timur-NTB \\ muhammadisnaini377@gmail.com
}

\begin{abstract}
The main focus which discus in this research is how the supervision is carried out by the principal as a supervisor. The principal's leadership function is to carry out school management and guidance through administration, management and leadership activities that are highly dependent on their abilities. The method used is a case study because it is to maintain the integrity of the system in a routine program. The purpose of this study is to determine the effectiveness of the principal's leadership as a supervisor in supervising teacher performance. Based on the analysis conducted concluded as follows. (1) The principal's supervision of teachers in primary schools has a very strategic role in determining policies and improving the quality of learning processes towards achieving the expected goals. (2) The principal is the school leader who regulates and determines administrative functions including the supervision function (supervision) individually or in groups, (3) In addition to the principal, the teacher also has a very decisive role in achieving the educational goals
\end{abstract}

\section{Keywords: leadership, supervision, elementary school}

\begin{abstract}
Abstrak: Fokus utama yang dikaji dalam peneitian ini adalah bagaimanakah pelaksanaan supervisi oleh kepala sekolah sebagai seorang supervisor. Fungsi kepemimpinan kepala sekolah yaitu harus melakukan pengelolaan dan pembinaan sekolah melalui kegiatan administrasi, manajemen dan kepemimpinan yang sangat tergantung pada kemampuannya. Metode yang digunakan yaitu studi kasus karena untuk menjaga keutuhan sistem dalam sebuah program rutin. Tujuan penelitian mengetahui efektivitas kepemimpinan kepala sekolah sebgai seorang supervisor dalam melakukan pengawasan terhadp kinerja guru. Berdasarkan analisis yang dilakukan disimpulkan sebagai berikut. (1) Supervisi kepala sekolah terhadap guru di sekolah dasar memiliki peran sangat strategis dalam menentukan kebijakan dan meningkatkan proses pembelajaran yang berkualitas menuju terwujudnya tujuan yang diharapkan. (2) Kepala sekolah adalah pemimpin sekolah yang mengatur dan menetapkan fungsi administrasi
\end{abstract}


termasuk di dalamnya fungsi pengawasan (supervisi) secara individual atau kelompok, (3) Selain kepala sekolah, guru juga mempunyai peran yang sangat menentukan tercapainya tujuan pendidikan.

Kata Kunci : kepemimpinan, supervisi, sekolah dasar

\section{A. Pendahuluan}

Sebagai lembaga pendidikan formal, sekolah bertujuan membentuk manusia yang berkepribadian, dalam mengembangkan intelektual peserta didik dalam rangka mencerdaskan kehidupan bangsa. Kepala sekolah sebagai pemimpin pendidikan perannya sangat penting untuk membantu guru dan peserta didik. Kepala sekolah sebagai pemimpin harus dapat memahami, mengatasi dan memperbaiki kekurangankekurangan yang terjadi di lingkungan sekolah.

Salah satu upaya untuk meningkatkan kualitas pendidikan, seorang kepala sekolah harus mampu meningkatkan kinerja para guru atau bawahannya. Banyak faktor yang dapat mempengaruhi kinerja sesorang, sebagai pemimpin sekolah harus mampu memberikan pengaruh-pengaruh yang dapat menyebabkan guru tergerak untuk melaksanakan tugasnya secara efektif sehingga kinerja mereka akan lebih baik. Sebagai pemimipin yang mempunyai pengaruh, ia berusaha agar nasihat, saran dan jika perlu perintahnya diikuti oleh guru-guru. Dengan demikian ia dapat mengadakan perubahan-perubahan dalam cara berpikir, sikap, tingkah laku yang dipimpinnya. Dengan kelebihan yang dimilikinya yaitu kelebihan pengetahuan dan pengalaman, ia membantu guru-guru berkembang menjadi guru yang profesional.

Fungsi kepemimpinan kepala sekolah yaitu harus melakukan pengelolaan dan pembinaan sekolah melalui kegiatan administrasi, manajemen dan kepemimpinan yang sangat tergantung pada kemampuannya. Terkait hal tersebut, kepala sekolah sebagai supervisor berfungsi untuk mengawasi, membangun, mengoreksi dan mencari inisiatif terhadap jalannya seluruh kegiatan pendidikan yang dilaksanakan di lingkungan sekolah, selain itu kepala sekolah sebagai pemimpin pendidikan berfungsi mewujudkan hubungan manusiawi (human relationship) yang harmonis dalam rangka membina dan mengembangkan kerja sama antarpersonal, agar secara serempak bergerak ke arah pencapaian tujuan melalui kesediaan melaksanakan tugas masing-masing secara efisien dan efektif.

Oleh karena itu, segala penyelenggaraan pendidikan akan mengarah kepada usaha meningkatkan mutu pendidikan yang sangat dipengaruhi oleh guru dalam melaksanakan tugasnya secara operasional. Untukitu kepala sekolah harus melakukan supervisi sekolah yang memungkinkan kegiatan operasional itu berlangsung dengan baik.

Melihat pentingnya fungsi kepemimpinan kepala sekolah sebagai supervisor dalam pengawasan kinerja guru di sekolah dasar, maka usaha untuk meningkatkan 
kinerja yang lebih tinggi bukanlah merupakan pekerjaan yang mudah bagi kepala sekolah. Karena kegiatan berlangsung sebagai proses yang tidak muncul dengan sendirinya. Pada kenyataannya banyak kepala sekolah yang sudah berupaya secara maksimal untuk meningkatkan kualitas pendidikan, salah satu caranya memotivasi para guru-guru akan memilki kinerja lebih baik tapi hasilnya masih lebih jauh dari harapan.

\section{B. Landasan Teori}

1. Pengertian Kepemimpinan

Kepala Sekolah sebagai pemimpin pendidikan, di lihat dari status dan cara pengangkatan tergolong pemimpin resmi, formal leader, atau status leader. Status leader bisa meningkat menjadifunctional leader. Tergantung dari prestasi dan kemampuan didalam memainkan peranannya sebagai pemimpin pendidikan sebagai sekolah yang telah diserahkan pertanggungjawaban kepadanya.

Istilah kepemimpinan pendidikan mengandung dua pengertian dimana kata "pendidikan" menerangkan dalam lapangan apa dan dimana kepemimpinan itu berlangsung, dan sekaligus menjadi sifat dan ciri-ciri bagaimana yang harus dimilki pemimpin itu. Menurut Hadari Nawawi: kepemimpinan adalah kemampuan menggerakkan, memberikan motivasi dan mempengaruhi orang-orang agar bersedia melakukan tindakan-tindakan yang terarah pada pencapaian tujaun (1993:81).

Kepala sekolah sebagai orang yang terpandang dilingkunag masyarakat sekolah. Ia sebagi pusat teladan bagi warga sekolah dan warga masyarakat di sekitar sekolah, karena itu ia kepala sekolah wajib melaksanakan petunjuk tentang usaha peningkatan ketahanan sekolah. Pada umumnya kepala sekolah memiliki tanggungjawab sebagi pemimpin dibidang pengajaran dan pengembangan kurikulum, administrasi personalia, administrasi personalia staf, hubungan masyarakat, "school Plant" dan perlengkapan organisasi di sekolah (W. Soemanto, 2006:38). Kepala sekolah dapat menerima tanggungjawab tersebut namun ia belum tentu mengerti dengan jelas bagaimana ia dapat menyumbang kearah perbaikan program pengajaran.

\section{Tipe Kepemimpinan}

Dalam upaya menggerakkan dan memotivasi orang lain agar melakukan tindakan-tindakan yang terarah pada pencapaian tujuan, seorang pemimpin melakukan dalam beberapa cara. Cara yang ia lakuakn merupakan pencerminan sikap serta gambaran tentang tipe (bentuk) kepemimpinan yang dijalankannya. Adapun gaya atau tipe kepemimpinan yang pokok atau juga disebut ekstrem ada tiga tipe atau bentuk kepemimpinan yaitu:

\section{a. Kepemimpinan Otoriter}

Kepemimpinan otoriter adalah kepemimpinan yang bertindak sebagai diktor terhadap anggota-anggota kelompoknya. Baginya memimpin 
adalah menggerakkan dan memaksa kelompok. Apa yang diperintahnya harus dilaksanakan secara utuh, ia bertindak sebagai penguasa dan tidak dapat dibantah sehingga orang lain harus tunduk kepada kekuasaanya. Ia menggunakan ancaman dan hukuman untuk menegakkan kepemimpinannya. Kepemimpian otoriter hanya akan menyebabkan ketidakpuasan dikalangan guru.

b. Kepemimpinan Laissez Faire

Bentuk kepemimpinan ini merupakan kebalikan dari kepemimpinan otoriter. Yang mana kepemimpinan laissez faire menitik beratkan kepada kebebasan bawahan untuk melakukan tugas yang menjadi tanggung jawabnya. Pemimpin lasses faire banyak memberikan kebebasan kepada personil untuk menentukan sendiri kebijaksanaan dalam melaksanakan tugas, tidak ada pengawasan dan sedikit sekali memberikan pengarahan kepada personilnya. Kepemimpinan Laissez Faire tidak dapat diterapkan secara resmi di lembaga pendidikan, kepemimpinan laissez faire dapat mengakibatkan kegiatan yang dilakuakn tidak terarah, perwujudan kerja simpang siur, wewenang dan tanggungjawab tidak jelas, yang akhirnya apa yang menjadi tujuan pendidikan tidak tercapai.

c. Kepemimpinan Demokratis

Bentuk kepemimpinan demokratis menempatkan manusia atau personilnya sebagai factor utama dan terpenting. Hubungan antara pemimpin dan orang-orang yang dipimpin atau bawahannya diwujudkan dalam bentuk human relationship atas dasar prinsip saling harga-menghargai dan hormat-menghormati. Dalam melaksanakan tugasnya, pemimpin demokratis mau menerima dan bahkan mengharapkan pendapat dan saran-saran dari bawahannya, juga kritik-kritik yang membangun dari anggota diterimanya sebagai umpan balik atau dijadikan bahan pertimbangan kesanggupan dan kemampuan kelompoknya. Kepemimpinan demokratis adalah kepemimpinan yang aktif, dinamis, terarah yang berusaha memanfaatkan setiap personil untuk kemajuan dan perkembangan organisasi pendidikan.

\section{Fungsi Kepemimpinan Pendidikan}

Kependidikan adalah proses menggerakkan, mempengaruhi, memberikan motivasi dan mengarahkan orang-orang dilembaga pendidikan untuk mencapai tujuan yang telah dirumuskan sebelumnya. Untuk mewujudkan tugas tersebut seorang pemimpin harus mampu bekerjasama dengan orang yang dipimpinnya. Seorang pemimpin harus tahu fungsi dan peranannya sebagai pemimpin. Adapun fungsi kepemimpinan pendidikan menurut Soekarto Indrafachrudi (1993:33) adalah pada dasarnya dapat dibagai menjadi dua yaitu: 
a. Fungsi yang bertalian dengan tujuan yang hendak dicapai

1) Pemimpin berfungsi memikirkan dan merumuskan dengan teliti tujuan kelompok serta menjelaskan supaya anggota dapat berkerjasama mencapai tujuan itu.

2) Pemimpin berfungsi memberi dorongan kepada anggota-anggota kelompok untuk menganalisis situasi supaya dapat dirumuskan rencana kegiatan kepemimpinan yang dapat memberi harapan baik.

3) Pemimpin berfungsi membantu anggota kelompok dalam memberikan keterangan yang perlu supaya dapat mengadakan pertimbangan yang sehat.

4) Pemimpin berfungsi menggunakan kesempatan dan minat khusus anggota kelompok.

b. Fungsi yang bertalian dengan suasana pekerjaan yang sehat dan menyenangkan

1) Pemimpin berfungsi memupuk dan memelihara kebersamaan di dalam kelompok.

2) Pemimpin berfungsi mengusahakan suatu tempat bekerja yang menyenangkan, sehingga dapat dipupuk kegembiraan dan semangat bekerja dalam pelaksanaan tugas.

3) Pemimpin dapat menanamkan dan memupuk perasaan para anggota bahwa mereka termasuk dalam kelompok dan merupakan bagian dari kelompok.

4. Syarat-Syarat Kepemimpinan Pendidikan

Mengenai syarat-syarat kepemimpinan, Tead (1935:31-34) dalam (Soekarna Indrafachrudin) bahwa syarat kepemimpinan pendidikan adalah:

a. Memiliki kesehatan jasmaniah dan rohaniah yang baik.

b. Berpegang teguh pada tujuan yang hendak dicapai.

c. Bersemangat

d. Jujur

e. Cakap dalam memberi bimbingan

f. Cepat serta bijaksana dalam mengambil keputusan

g. Cerdas 
h. Cakap dalam hal mengajar dan menaruh kepercayaan kepada yang baik dan berusaha mencapainya

\section{Metode Penelitian}

Metode penelitian menggambarkan tentang pendekatan, tipe, jenis suatu penelitian. Penelitian ini menggunakan pendekatan kualitatif, dengan metode studi kasus karena penulis ingin mempertahankan keutuhan subjek sebagai satu kesatuan best practice. Kepemimpinan Kepala Sekolah sebagai Seorang Supervisor dalam Pengawasan Kinerja Guru di Sekolah Dasar. Studi kasus menurut Sukmadinata (2012:64) merupakan suatu penelitian yang dilakukan terhadap suatu kesatuan, baik berupa program, kegiatan, peristiwa, atau kelompok individu yang terikat oleh tempat, waktu, atau ikatan tertentu.

Studi kasus dipilih sebagai metode karena bertujuan untuk mengembangkan metode kerja yang efisien, maknanya peneliti mengadakan telaah secara mendalam tentang suatu kasus, kesimpulan hanya berlaku atau sebatas pada kasus tertentu saja (Iskandar, 2008:207).

1. Lokasi Penelitian

Lokasi penelitian di SDN 7 Terara, Desa Terara Kecamatan Terara Kabupaten Lombok Timur.

2. Subjek Penelitian

Penentuan subjek dilakukan dengan menggunakan teknik populasi, karena semua guru yang ada di SDN 7 Terara menjadi subjek penelitian.

3. Teknik Pengumpulan Data

Pengumpulan data dilakukan dengan menggunakan instrumen supervisi yang dilakukan untuk menilai kinerja guru setiap bulan dan dikumpulkan selama satu tahun untuk mengisi Sasaran Kerja Pegawai sebagai penilaian akhir Tahun. Teknik ini dilakukan dengan cara wawancara, observasi, dan dokumentasi.

4. Teknik Analisis Data

Teknik analisis data yang digunakan adalah teknik analisis deskripftif kualitatif, untuk menggambarkan data hasil supervisi selama satu tahun. Data yang terkumpul selanjutnya dianalisis dengan menguraikan data hasil supervisi secara jelas dan terperinci.

D. Pembahasan

1. Peran Kepemimpinan Kepala Sekolah sebagai Supervisor dalam Pengawasan Kinerja Guru di Sekolah Dasar 
Keberhasilan seorang pemimpin akan terwujud apabila pemimpin tersebut memperlakukan orang lain atau bawahannya dengan baik, serta memberikan motivasi agar mereka menunjukan performance yang tinggi dalam melaksanakan tugas. Menurut Hadari Nawawi (1983:81) kepemimpinan adalah kemampuan menggerakan, memberikan motivasi dan mempengaruhi orang-orang agar bersedia melakukan tindakan-tindakan yang terarah pada pencapaian tujuan melalui keberanian mengambil keputusan tentang kegiatan yang harus dilakukan. Dari uraian diatas dapat disimpulkan bahwa kepemimpinan kepada sekolah sebagai Seorang Supervisor dalam pengawasan Kinerja Guru akan berahasil jika kepala sekolah memperhatikan hasil yang dicapai serta memperlakukan guru dengan baik, sehingga mereka mampu menunjukan performace yang lebih baik.

Kinerja guru merupakan aktivitas yang dilakukan guru sesuai dengan profesi yang diembannya, untuk dapat melakukan tindakan yang sesuai dengan profesi yang diembannya sangat terkait dengan ada tidaknya kepuasan dalam bekerja. Kepuasan bekerja berhubungan erat dengan motivasi kerja. Menurut Hamid Darmadi (1994:107) kepuasan kerja timbul dengan baik jika seseorang memiliki motivasi kerja yang baik pula.

Asmara (dalam Hamid Darmadi;1994:118) menjelaskan bahwa tindakan kepemimpinan kepala sekolah terhadap kematangan kerja guru dan kepuasan kerja guru berkorelasi positif, maksudnya kematangan kerja yang tinggi cenderung diikuti oleh kepuasan kerja yang tinggi pula. Berdasarkan pendapat tersebut diatas dapat disimpulkan bahwa kepemimpinan kepala sekolah sebagai seorang supervisor dalam pengawasan kinerja guru sangat dipengaruhi oleh kepemimpinannya yang dapat meningkatkan kepuasan sehingga aktivitas kerja guru meningkat. Kepemimpinan akan terwujud apabila seseorang pemimpin atau kepala sekolah memberikan petunjuk-petunjuk kepada bawahannya, mengadakan pengawasan, motivasi sehigga dapat menimbulkan kepuasan bagi guru.

\section{Model Supervisi Kepala Sekolah}

Setiap kepala sekolah harus memiliki keterampilan teknis berupa kemampuan menerapkan teknik-teknik supervisi pembelajaran yang tepat. Kepala sekolah dapat menggunakan teknik individual atau kelompok.

\section{a. Teknik supervisi individual}

Teknik supervisi individual adalah pelaksanaan supervisi perorangan. Kepala sekolah tidak hanya berhadapan dengan seorang guru, sehingga melalui supervisi akan diketahui kualitas pembelajarannya. Teknik-teknik supervisi ini dapat dilakukan dengan kunjungan kelas, observasi kelas, pertemuan individual, kunjungan antarkelas, dan menilai diri sendiri. Kunjungan kelas adalah teknik pembinaan guru oleh kepala sekolah untuk mengamati proses pembelajaran di kelas. Tujuannya untuk menolong guru dalam mengatasi masalah di dalam kelas. Observasi kelas ialah mengamati 
proses pembelajaran secara teliti di kelas. Tujuannya untuk memperoleh data obyektif aspek-aspek situasi pembelajaran dan kesulitan-kesulitan guru dalam usaha memperbaiki proses pembelajaran.

Aspek-aspek yang diobservasi ialah usaha-usaha dan aktivitas guru-peserta didik dalam proses pembelajaran, cara menggunakan media pengajaran, variasi metode, ketepatan penggunaan media dengan materi, ketepatan mengunakan metode dengan materi, dan reaksi mental para peserta didik dalam proses belajar mengajar. Pelaksanaan observasi kelas malalui tahap persiapan, pelaksanaan, penutupan, penilaian hasil observasi, dan tindak lanjut.

Pertemuan individual ialah satu pertemuan, percakapan, dialog, tukar pikiran antara pengawas sekolah dan guru. Tujuannya untuk guru agar berkonsultasi dengan pengawas guna memperbaiki segala kelemahan dan kekurangan. Bisa dilakukan dengan: 1) Classroom-conference, yaitu percakapan individual yang dilaksanakan di dalam kelas ketika peserta didik sedang meninggalkan kelas; 2) Officeconference, yakni percakapan individual yang dilaksanakan di ruang kepala sekolah atau ruang guru, yang sudah dilengkapi dengan alat-alat bantu yang dapat digunakan untuk memberikan penjelasan kepada guru; 3) Causal-conference, yaitu percakapan individual yang bersifat informal, yang secara kebetulan bertemu dengan guru; 4) Observational visitation, yaitu percakapan individual yang dilaksanakan setelah pengawas sekolah melakukan kunjungan kelas atau observasi kelas. Kunjungan antar kelas adalah guru yang satu berkunjung ke kelas yang lain di sekolah itu sendiri. Tujuannya adalah untuk berbagi pengalaman dalam pembelajaran. Sedangkan menilai diri sendiri adalah penilaian diri yang dilakukan oleh diri guru itu sendiri secara obyektif.

\section{b. Teknis supervisi kelompok}

Teknik supervisi kelompok adalah cara melaksanakan program supervisi yang ditujukan kepada dua orang guru atau lebih. Supervisi ini dilakukan kepada kelompok guru yang memiliki masalah atau kebutuhan atau kelemahan-kelemahan yang sama. Supervisi kelompok, yaitu: supervisi yang dilakukan terhadap kegiatan kepanitiaan, kerja kelompok, laboratorium, membaca terpimpin, demonstrasi pembelajaran, darmawisata, kuliah/studi, diskusi panel, perpustakaan, organisasi profesional, pertemuan guru, lokakarya atau konferensi kelompok.

Dewasa ini sistem pembelajaran tradisional yang terlalu berpusat pada kegiatan guru mulai ditinggalkan. Proses pembelajaran akan berhasil dengan baik, jika terdapat komunikasi yang baik antara murid, guru, dan lingkungan belajar mereka. Proses pembelajaran yang baik adalah proses belajar yang memberikan makna bagi peserta didik, proses belajar harus menyenangkan bagi siswa. Maksud dari pengertian menyenangkan di sini adalah bukan berarti proses pembelajaran yang berlangsung dengan santai, guru memberikan nilai yang baik (tidak sesuai dengan penguasaan kompetensi belajar siswa), guru tidak pernah memberikan tugas, guru jarang masuk, disiplin yang longgar, dan sebagainya, yang itu semua mendorong siswa untuk 
malas belajar. Akan tetapi yang dimaksud menyenangkan dalam pengertian ini adalah proses belajar, di mana guru dapat memberikan variasi model pembelajaran yang menarik, menggunakan media pembelajaran yang menarik, serta mengelola proses pembelajaran dengan baik, sehingga siswa merasa senang, dan dengan penuh kesadaran siswa akan belajar dan menyelesaikan tugas-tugas mereka dengan senang hati.

Model pembelajaran yang demikian seringkali dikenal dengan pembelajaran "PAKEM" (Pembelajaran Aktif, Kreatif dan menyenangkan). Salah satu bentuk sarana pembelajaran yang dapat membuat anak aktif belajar adalah dengan E-learning. Dengan E-learning ini anak dapat belajar dengan tidak terikat pada ruang dan waktu. Anak akan dapat belajar kapan saja, tidak terikat pada kegiatan pembelajaran di dalam kelas. Proses E-learning dalamkegiatan belajar siswa akan sangatmenyenangkan, sebab dengan proses pembelajaran berbasis komputer ini disajikan materi pembelajaran yang interaktif. Siswa dapat memilih sendiri materi pembelajaran yang diperlukan, sehingga pemahaman siswa terhadap materi pembelajaran dapat ditingkatkan. Sebagai alternatif E-learning memberikan harapan besar pada peningkatan mutu pendidikan di Indonesia, akan tetapi bukan berarti proses pembelajaran dengan E-learning mudah untuk dilaksanakan. Sistem pembelajaran seperti ini akan dapat dilaksanakan di kotakota, namundewasa ini kemudahan akan didapatkan sampai ke pelosok sekalipun. Kita sangat mudah mendapatkan materi-materi pembelajaran berbasis E-learning, apalagi akses internet yang sudah sangat mudah. Bahkan di daerah-daerah yang jauh dari kota hal tersebut menjadi hal yang tidak mustahil. Dari uraian di atas jelaslah bahwa E-learning itu merupakan kebutuhan yang memberikan harapan besar pada peningkatan kualitas pendidikan di Indonesia, tetapi untuk melaksanakan E-learning dibutuhkan perjuangan yang besar, baik dalam hal penyediaan sarana/prasarana penunjang maupun kesiapan sumber daya manusianya.

\section{Peran Guru dalam Mencapai Tujuan Pendidikan}

Perkembangan teknologipada era globalisasisaatinitelah memberikan pengaruh yang signifikan terhadap dunia pendidikan. Model pembelajaran konvensional yang banyak mewarnai pembelajaran di Indonesia, dirasakan masih terdapat kekurangan, baik dalam proses pembelajaran maupun hasil belajarnya. Selain model pembelajaran konvensional masih berpusat pada guru, juga model pembelajaran ini belum dapat melayani peserta didik sesuai dengan kebutuhan masing-masing, karena proses pembelajarannya yang dilakukan di ruang kelas dalam jangka waktu tertentu.

Model pembelajaran yang dapat meningkatkan motivasi belajar anak dengan memanfaatkan teknologi adalah melalui e-learning (pembelajaran elektronik). E-learning adalah pembelajaran yang relatif baru di Indonesia, oleh karena itu belum begitu banyak dimanfaatkan oleh masyarakat, selain memang membutuhkan infrastruktur yang relatif masih mahal. E-learning (electronic learning) adalah pembelajaran baik secara formal maupun informal yang dilakukan melalui media elektronik, seperti internet, intranet, CD-ROM, video tape, DVD, TV, handphone, 
PDA, dan lain-lain (Lende, 2004). Akan tetapi, dalam e-learning pembelajaran yang lebih dominan menggunakan internet (berbasis web).

Proses pembelajaran melalui e-learning diharapkan siswa dapat belajar di mana saja dan kapan saja tanpa hadirnya guru di dekat mereka. Misalnya e-learning menggunakan CD-ROM (multimedia), siswa dapat membuka pelajaran tersebut kembali di rumah dan dapat belajar sendiri. Mengapa demikian? Dalam multimedia, pelajaran dapat dipelajari sendiri karena terdapat feedback dan dilengkapi animasi yang cukup menarik. Diharapkan agar siswa akan termotivasi dalam belajarnya karena penyajiannya yang seperti permainan. Selain itu, sesuatu hal yang baru biasanya membuat seseorang lebih tertarik untuk mengetahui dan mencobanya. Apalagi dengan kemajuan teknologi, siswa akan merasa tertantang untuk mampu menggunakannya.

Begitu pula e-learning berbasis web, guru dapat memberikan materipelajarannya lewat sarana internet yang dapat diakses oleh siswa setiap saat dan di mana saja. Siswa juga tidak perlu harus selalu belajar di kelas untuk mendapatkan informasi mengenai materi yang ingin diperolehnya. Bahkan, siswa dapat mengembangkan proses belajarnya dengan mencari referensi dan informasi dari sumber lain, sehingga wawasan siswa menjadi berkembang.

Kemampuan akses ke internet tidak hanya didasarkan kemampuan memiliki komputer yang dapat memasuki jaringan internet, melainkan juga dibutuhkan keterampilan menjelajah dunia maya tersebut dalam rangka memperoleh informasi yang dibutuhkan. Apabila seseorang tidak memiliki keterampilan menjelajah internet maka ia akan mengeluarkan dana yang cukup besar dan waktu yang lama untuk memperoleh situs informasi yang dibutuhkan. Pada posisi inilah e-learning berfungsi mendekatkan seseorang dengan sumber informasi yang diperlukan.

Setidaknya ada tiga fungsi e-learning terhadap kegiatan pembelajaran di dalam kelas (classroom instruction), yaitu: (1) sebagai tambahan (suplemen) yang sifatnya pilihan (opsional); tidak ada kewajiban bagi peserta didik untuk mengakses materi e-learning. Sekalipun sifatnya opsional, peserta didik yang memanfaatkannya tentu akan memiliki tambahan pengetahuan atau wawasan. (2) pelengkap (complement); materie-learningdiprogramkanuntukmenjadimaterireinforcement(pengayaan)atau remedial bagi peserta didik di dalam mengikuti kegiatan pembelajaran konvensional. (3) pengganti (substitusi); e-learning sebagai alternatif model pembelajaran.

Pemanfaatan e-learning berpengaruh terhadap tugas guru dalam proses pembelajaran. Dahulu, proses pembelajaran didominasi oleh peran guru, karena itu disebut the era of teacher. Kini, proses pembelajaran banyak didominasi oleh peran guru dan buku (the era of teacher and book). Di masa mendatang proses pembelajaran akan didominasi oleh peran guru, buku, dan teknologi (the era of teacher, book, and technology).

Indonesia yang luas dan terdiri dari beberapa pulau, mengakibatkan terjadinya kesenjangan kesempatan memperoleh pendidikan untuk masyarakat yang ingin 
belajar. Peran e-learning sangat sesuai dengan kondisi geografis kita seperti ini. Dengan berkembangnya teknologi informasi, kita dapat mengambil manfaat dari teknologi tersebut dalam menciptakan pembelajaran yang berkualitas, efektif, dan efisien.

Melalui kegiatan e-learning terutama melalui internet, dimungkinkan berkembangnya fleksibilitas belajar yang tinggi. Artinya, peserta didik dapat mengakses bahan-bahan belajar setiap saat dan berulang-ulang. Peserta didik juga dapat berkomunikasi dengan pendidik setiap saat. Dengan kondisi yang demikian ini, peserta didikdapatlebih memantapkan penguasaannya terhadap materipembelajaran. Kegiatan e-learning, beberapa manfaat yang diperoleh guru/dosen antara lain adalah bahwa guru / dosen dapat lebih mudah melakukan pemutakhiran bahan-bahan belajar yang menjadi tanggung jawabnya sesuai dengan tuntutan perkembangan keilmuan yang terjadi; mengembangkan diri atau melakukan penelitian guna peningkatan wawasannya karena waktu luang yang dimiliki relatif lebih banyak.

Walaupun demikian, pemanfaatan internet atau e-learning juga tidak terlepas dari berbagai kekurangan dan berbagai kritik, antara lain: kurangnya interaksi secara psikologis antara guru dan siswa, atau bahkan antarsiswa itu sendiri. Hal ini bisa memperlambat terbentuknya values dalam proses pembelajaran. Selain itu, tidak semua tempat tersedia fasilitas internet; kurangnya mereka yang mengetahui dan memiliki keterampilan mengenai komputer dan internet.

Akan tetapi, kita harus berani untuk memulainya, karena setiap perubahan atau inovasi selalu ada kelebihan dan kekurangannya. Banyak pihak yang berpendapat bahwa pembelajaran e-learning sebagai cara belajar baru yang cukup menjanjikan untuk orang belajar sendiri, mandiri, tidak terbatas oleh jarak, ruang, dan waktu. Pelaksanaan pembelajaran ini menuntut profesionalisme yang tinggi dari berbagai pihak penyelenggaranya. Oleh karena itu, perlu dipersiapkan sumber daya manusia, baik penyelenggara maupun instruktur pembelajaran yang mempunyai kemampuan yang cukup memadai.

Agar e-learning ini dapat memberikan pengaruh yang cukup signifikan terhadap pembelajaran dengan kondisi masyarakat kita, sebaiknya e-learning ini dilakukan secara bertahap, dari mulai e-learning sebagai suplemen sampai pada e-learning sebagai substitusi. Di Indonesia, memang e-learning baru sesuai sebagai suplemen karena banyak faktor yang berpengaruh, terutama e-learning masih relatif baru. Selain itu, perlu dipikirkan mengenai evaluasi pembelajaran dengan cara e-learning yang dapat mengukur hasil belajar peserta didik dengan baik, walaupun masih terjadi diskusi akademik yang intensif dalam hal evaluasi pembelajaran ini.

Seperti diungkapkan di atas, bahwa pelaksanaan e-learning tidaklah mudah. Banyak sekali faktor penghambat bagi pelaksanaan e-learning ini. Terutama di daerah pedesaan, hambatan-hambatan dalam pelaksanaan e-learning adalah sebagai berikut. 
a) Kesiapan Tenaga Pengajar

Dalam pelaksanaan e-learning ini menuntut guru untuk dapat mengoperasionalkan berbagai bentuk media pembelajaran elektronik, seperti misalnya, VCD, komputer, internet, dan sebagainya. Akan tetapi tampaknya sebagian besar guru masih mengalami hambatan dalam mengoperasionalkan alat-alat tersebut, terutama mengoperasionalkan komputer. Padahal dalam pembelajaran berbasis e-learning ini guru dituntut untuk dapat mengoperasionalkan komputer, membuat bahan-bahan ajar berbasis komputer yang bersifat interaktif, misalnya dengan menggunakan powerpoint, flash, dan mengakses internet. Akan tetapi komptensi dalam menggunakan media pembelajaran elektronik terutaman pemanfaatan komputer dan internet ternyata masih jauh dari yang diharapkan. Dengan kata lain sebagian besar tenaga pengajar belum siap untuk menerapkan e-learning secara utuh. Walaupun dengan e-learning siswa dapat belajar tanpa kehadiran seorang guru, akan tetapi peran guru tetaplah sangat penting. Gurulah yang memimpin proses pembelajaran.

b) Kesiapan dan Motivasi Siswa

Sistem pembelajaran berbasis e-learning ini, siswa sebagai pelaku utama dalam proses pembelajaran diharapkan memiliki motivasi dan kemampuan dasar yang cukup dalam kegiatan pembelajaran. Kondisi geografis, dan sosial ekonomi siswa yang berada di daerah pegunungan, menjadikan motivasi dan kemampuan dasar siswa dalam penggunaan alat-alat yang berkaitan dengan e-learning sangat bervariasi. Siswa yang berada di lingkungan sekitar sekolah mungkin masih mempunyai motivasi yang besar dan kemampuan awal dalam mengoperasionalkan alat-alat ekeltronik yang lumayan. Akan tetapi bagi siswa yang tempat tinggalnya jauh dari sekolah, ditambah dengan kondisi sosial ekonomi yang kurang mendukung mengakibatkan sebagian besar siswa masih sangat ketinggalan dalam hal pengunaan alat-alat teknologi informasi dan komunikasi, misalnya komputer dan internet.

c) Dukungan Orang Tua

Orang tua siswa memiliki kepedulian yang sangat besar dalam hal pendidikan anak-anak mereka. Akan tetapi kondisi sosial ekonomi yang beraneka ragam, maka dukungan orang tua terhadap sistem pembelajaran seperti ini juga masih kurang. Ini terbukti sebagian besar siswa masih sangat tergantung dengan alat-alat pembelajaran elektronik yang disediakan di sekolah. Mereka rata-rata belum dapat menggunakan alat-alat pembelajaran elektronik di luar sekolah. Di lain pihak, kondisi daerah yang jauh dari pusat kota, juga belum banyak penyedia jasa-jasa layanan teknologi informasi dan komunikasi. 
d) Ketersediaan Sarana dan Prasarana

Diakui atau tidak, sebagan besar sekolah terutama yang berada di daerah pedesaan belum tersedia jasa layanan internet, terkecuali untuk sekolah-sekolah yang "nekat" untuk menyediakan jasa layanan tersebut. Jauhnya sekolah ini dari pusat kota mengakibatkan jangkauan telekomunikasi yang sangat terbatas, sehingga penggunaan internet masih dalam tataran yang sangat terbatas. Itulah sebabnya para guru dan siswa sebagian besar belum dapat menggunakan jasa internet ini sebagai media pembelajaran. Selain masih rendahnya penggunaan internet dalam proses pembelajaran, juga kurang didukung oleh teknisi yang baik. Sekolah kebayakan belum memiliki teknisi dalam bidang teknologi informasi dan komunikasi yang profesional. Itulah sebabnya jika terdapat kesulitan dan kerusakan masih sangat tergantung pada teknisi dari luar.

\section{E. Penutup}

Berdasarkan pembahasan diatas maka dapat disimpulkan beberapa poin utama mengenai kepemimpinan kepala sekolah sebgai seorang supervisor, yaitu: Supervisi kepala sekolah terhadap guru di sekolah dasar memiliki peran sarangat strategis dalam menentukan kebijakan dan meningkatkan proses pembelajaran yang berkualitas menuju terwujudnya tujuan yang diharapkan. Kepala sekolah adalah pemimpin sekolah yang mengatur dan menetapkan fungsi administrasi termasuk didalamnya fungsi pengawasan (supervisi) secara individual atau kelompok, Selain kepala sekolah, guru juga mempunyai peran yang sangat menentukan tercapainya tujuan pendidikan. Inovasi pembelajaran dapat dilakukan setelah supervisi oleh kepala sekolah dengan melihat hasil supervisi.

\section{DAFTAR PUSTAKA}

Arikunto, Suharsimi.(2006).ProsedurPenelitian SuatuPendekatan Praktik.Jakarta:Rineka Cipta.

Asmara, Husna. (1996). Kepemimpinan, Teori dan Aplikasi. Jakarta: Alfabeta.

Darmadai, Hamid. (1994). Metode Penelitian Pendidikan dan Sosial. Jakarta:Alfabeta.

Djamarah, 2002. Prestasi Belajar dan Kompetensi Guru. Surabaya : Usaha Nasional.

Hadari, Nawawi. (1983). Metode Penelitian Bidang Sosial. Jogjakarta:Gadjah Mada University Press.

Indrafachrudi, Soekarto. (1993). Bagaimana Memimpin Sekolah Yang Efektif. Bogor:Ghalia Idonesia. 
El-Tsaqafah: Jurnal Jurusan PBA, Vol. 18, No.2, Desember 2019

Iskandar. (2008). Metodologi Penelitian Pendidikan dan Sosial (Kuantitatif dan Kualitatif). Jakarta:Gaung Persada Press.

Kamus Besar Bahasa Indonesia. https:/ / kbbi.web.id.

Soemanto, Wasty. (2006). Psikologi Pendidikan, Landasan Kerja Pemipin Pendidikan. Jakarta:Rineka Cipta.

Sukmadinata, Nana Syaodh. (2012). Metode Penelitian Pendidikan. Bandung:PT Remaja Rosdakrya.

Yustini, 2010. Implementasi Supervisi Akademik Oleh Kepala Sekolah Untuk Meningkatkan Kualitas Pembelajaran Pada Guru Smp Negeri 11 Kota Lubuk Linggau. Bengkulu: Universitas Bengkulu. 